\title{
Increased expression of apoptosis signalling receptors by alveolar macrophages in sarcoidosis
}

\author{
H. Dai*, J. Guzman ${ }^{+}$, U. Costabel*
}

Increased expression of apoptosis signalling receptors by alveolar macrophages in sarcoidosis. H. Dai, J. Guzman, U. Costabel. ERS Journals Ltd 1999.

ABSTRACT: The Fas receptor (FasR) and the tumour necrosis factor (TNF) receptor $55 / 60 \mathrm{kDa}$ (TNFR1) are recognized as apoptosis signalling receptors. They are known to be expressed by lymphocytes in association with immune regulation and immunological disorders. This study aimed to investigate the expression of FasR and TNFR1 by alveolar macrophages $(\mathrm{AM})$ in patients with sarcoidosis.

Bronchoalveolar lavage (BAL) was performed in 12 patients with active sarcoidosis and 11 control subjects. BAL cells were characterized by monoclonal antibodies using a peroxidase-antiperoxidase method.

Both FasR and TNFR1 were expressed on a higher percentage of AM in sarcoidosis with respect to control subjects (mean \pm sem $40.8 \pm 3.1 \%$ versus $14.9 \pm 1.7 \%, p<0.001$ and $61.9 \pm 3.3 \%$ versus $23.1 \pm 4.1 \%, p<0.001$, respectively). There was a close relationship between the expression of FasR and TNFR1 on AM $(r=0.86, p<0.001)$. The percentages of $\mathrm{FasR}^{+} \mathrm{AM}$ and $\mathrm{TNFR1}^{+} \mathrm{AM}$ were in direct proportion to the percentage of BAL lymphocytes $(r=0.75$ and 0.84$)$, the $C D 4 / C D 8$ ratio $(r=0.78$ and 0.78$)$, and the percentage of the $\mathrm{CD14}{ }^{+} \mathrm{AM}$ subset $(\mathrm{r}=\mathbf{0 . 7 7}$ and 0.87$), \mathrm{p}<0.001$ for all correlations.

This study indicates that alveolar macrophages expressing apoptotic receptors are increased in patients with active sarcoidosis. Further studies are required to determine whether these alveolar macrophages from patients with sarcoidosis undergo apoptosis more readily than those from control subjects.

Eur Respir J 1999; 13: 1451-1454.
*Dept of Pneumology and Allergy, Ruhrlandklinik, Medical Faculty, University of Essen, Germany. ${ }^{+}$General and Experimental Pathology, Ruhr University, Bochum, Germany.

\author{
Correspondence: U. Costabel \\ Ruhrlandklinik \\ Tüschener Weg 40 \\ D-45239 Essen \\ Germany \\ Fax: 492014334029
}

Keywords: Alveolar macrophage

apoptosis

Fas receptor

sarcoidosis

tumour necrosis factor receptor

Received: July 141998

Accepted after revision March 151999

Supported by Arbeitsgemeinschaft zur Förderung der Pneumologie an der Ruhrlandklinik (AFPR)
Programmed cell death or apoptosis results from the activation of an internally encoded suicide programme by a variety of extrinsic and intrinsic signals, which allows for the efficient elimination of unwanted cells $[1,2]$. Many studies have confirmed the importance of apoptosis in the regulation of the immune system $[3,4]$.

Apoptosis can be triggered by ligation of the Fas receptor (FasR) or the tumour necrosis factor (TNF) receptor 55/60 kDa (TNFR1) on the cell surface with Fas ligand or TNF, respectively. Both FasR and TNFR1 belong to the TNF receptor superfamily and contain a unique cytoplasmic death domain that is necessary and sufficient for the transduction of the apoptotic signals, so they are called apoptosis signalling receptors [4-6]. FasR and TNFR1 can be expressed on a variety of cells, including thymocytes and haematopoietic lineage cells [7-10]. Expression of FasR has been shown to be upregulated on peripheral blood lymphocytes from patients with systemic lupus erythematosus [11]. The level of expression was higher on T-cells at lesions of invaded organs than on peripheral blood lymphocytes $[12,13]$. In addition to FasR, expression of TNFR1 has also been demonstrated on peripheral blood lymphocytes in sarcoidosis and hypersensitivity pneumonitis [12]. Apoptosis has been observed in peripheral blood lymphocytes from patients with systemic lupus erythematosus and in aqueous humor lymphocytes of uveitis resulting from sarcoidosis [11,
13]. Apoptosis through the FasR/Fas ligand pathway has been shown to be associated with the resolution of inflammation in a mouse model of acute lung injury [14]. It seems that apoptosis plays a role in systemic and local immune regulation.

Sarcoidosis is a systemic granulomatous disorder of unknown origin, commonly affecting lungs, characterized by a chronic T-cell-macrophage inflammatory process and granuloma formation [15]. The macrophage is recognized as a pivotal regulator of inflammation and immunity [15, 16]. Little information is available about the expression of FasR and TNFR1 by alveolar macrophages (AM) and the relation to the pulmonary disease processes. This background prompted the present investigation of the expression of FasR and TNFR1 on AM from patients with sarcoidosis.

\section{Material and methods}

\section{Study population}

Twelve consecutive patients with active pulmonary sarcoidosis (four females and eight males, average age $43 \pm 9$ yrs, one smoker) were investigated. No patient was under treatment with steroids. The diagnosis was established on the basis of compatible clinical and radiographic features, 
histological evidence of noncaseating granulomata on transbronchial biopsy or an increased CD4/CD8 ratio in bronchoalveolar lavage (BAL) fluid, and the exclusion of other granulomatous lung diseases. Criteria of disease activity were: 1) recently developed or increasing symptoms such as cough, dyspnoea, weakness, fever, and arthralgia, and/or 2) chest radiographic evidence of progressive disease, and/or 3) deterioration of lung function tests. According to chest radiographic staging, seven patients had stage 1 disease, four had stage 2, and one had stage 3 .

The control subjects consisted of 11 patients (four females and seven males, average age $47 \pm 11$ yrs, two smokers). They had no evidence of interstitial disease, underwent diagnostic bronchoscopy for various reasons and had normal BAL cytology.

Written, informed consent was obtained according to institutional guidelines.

\section{Bronchoalveolar lavage}

BAL was performed by instillation of a total of $200 \mathrm{~mL}$ of sterile isotonic saline in $10 \times 20 \mathrm{~mL}$ aliquots into the right middle or left lingular lobe via a fibreoptic bronchoscope, with immediate aspiration by gentle suction after each aliquot. The recovered fluid was filtered through two layers of gauze and subsequently centrifuged at $500 \times$ $g$ for $10 \mathrm{~min}$. The cells were counted in a haemocytometer. Cell viability was assessed by Trypan blue exclusion. Cell differentials were made on smears stained with MayGrünwald-Giemsa by counting 600 cells [17].

\section{Immunocytochemical analysis}

The monoclonal antibodies $(\mathrm{mAb})$ used in this analysis included CD3, CD4, CD8 (Dako, Copenhagen, Denmark), CD14 (Coulter, Miami, FL, USA), FasR (Upstate Biotechnology Incorporated, New York, NY, USA), and TNFR1 (Bender MedSystems, Vienna, Austria). The peroxidaseantiperoxidase (PAP) method was applied to identify membrane antigens on the freshly recovered BAL cells as previously described [18]. Briefly, $10 \mu \mathrm{L}$ cell suspension $\left(5 \times 10^{6}\right.$ cells $\left.\cdot \mathrm{min}^{-1}\right)$ was added to the reaction areas of adhesion slides (Bio-Rad, Munich, Germany). After the cells had settled on the glass surface, they were incubated with $\mathrm{mAb}$ for $15 \mathrm{~min}$ and fixed with $0.05 \%$ glutaraldehyde for $5 \mathrm{~min}$. This was followed by an incubation with a gelatin containing medium supplemented with $10 \%$ swine serum and $0.2 \%$ bovine serum albumin to prevent nonspecific binding of immunoglobulin to the glass and cells. Next, the cells were incubated with rabbit anti-mouse immunoglobulin $(\mathrm{Ig}) \mathrm{G}$, then with swine anti-rabbit IgG and finally with the rabbit PAP immunocomplex, each incubation lasting $5 \mathrm{~min}$ (all reagents from Dako). Diaminobenzidine was used as the substrate to visualize the reaction, and $\mathrm{OsO}_{4}$ for postfixation. Specificity of the immunostaining was determined by omitting the primary $\mathrm{mAb}$ on a reaction area and using mouse IgG instead. No cross-reaction was observed. To evaluate the percentage of positive cells, at least 200 macrophages or lymphocytes were counted under a light microscope.

\section{Statistics}

All data are expressed as mean \pm SEM. The differences between the two groups were compared using a Student's ttest (for parametric data) or a Mann-Whitney U-test (for nonparametric data). Spearman's rank correlation coefficients were calculated to estimate the correlation between $\mathrm{FasR}^{+} \mathrm{AM}$ or $\mathrm{TNFR} 1^{+} \mathrm{AM}$ and other parameters. A p-value of 0.05 was accepted as statistically significant.

\section{Results}

\section{BAL cytology}

Patients with sarcoidosis had significantly higher lymphocyte percentages and lower macrophage percentages of BAL cells than control subjects. The data are summarized in table 1.

\section{Immunocytology}

The percentages of both $\mathrm{FasR}^{+} \mathrm{AM}$ and $\mathrm{TNFR}^{+} \mathrm{AM}$ were almost three-fold elevated in sarcoidosis as compared with control subjects $(40.8 \pm 3.1 \%$ versus $14.9 \pm 1.7 \%, \mathrm{p}<$ 0.001 , and $61.9 \pm 3.3 \%$ versus $23.1 \pm 4.1 \%$, $\mathrm{p}<0.001$, respectively) (fig. 1). The percentage of $\mathrm{CD} 14^{+} \mathrm{AM}$ was also increased in sarcoidosis $(74.6 \pm 2.2 \%$ versus $60.5 \pm 2.6 \%$, $\mathrm{p}<0.001)$. The profile of BAL T-lymphocytes was characteristic for sarcoidosis with a marked increase in the CD4/CD8 ratio (table 1).

\section{Correlation of FasR ${ }^{+} A M$ or $T N F R 1^{+} A M$ with other pa- rameters}

A close correlation was found between the proportion of $\mathrm{FasR}^{+} \mathrm{AM}$ and $\mathrm{TNFR}^{+} \mathrm{AM}(\mathrm{r}=0.86, \mathrm{p}<0.001)$. The percentages of both $\mathrm{FasR}^{+} \mathrm{AM}$ and $\mathrm{TNFR} 1^{+} \mathrm{AM}$ correlated positively with the percentages of BAL lymphocytes ( $\mathrm{r}=$ 0.75 and 0.84 ), and of the $\mathrm{CD} 14^{+} \mathrm{AM}$ subset ( $\mathrm{r}=0.77$ and 0.87 ), and the $\mathrm{CD} 4 / \mathrm{CD} 8$ ratio ( $\mathrm{r}=0.78$ and 0.78$)$, and negatively with the AM percentage (-0.75 and -0.86$), \mathrm{p}<0.001$ for all correlations.

Table 1. - Cell counts and profile of lymphocytes in bronchoalveolar lavage fluid

\begin{tabular}{lrrc}
\hline & $\begin{array}{c}\text { Sarcoidosis } \\
(\mathrm{n}=12)\end{array}$ & $\begin{array}{c}\text { Control } \\
(\mathrm{n}=11)\end{array}$ & p-values \\
\hline Total cells $\times 10^{6}$ & $24.1 \pm 6.5$ & $14.3 \pm 3.0$ & $\mathrm{NS}$ \\
Macrophages \% & $50.9 \pm 4.0$ & $88.2 \pm 1.6$ & $<0.001$ \\
Lymphocytes \% & $45.8 \pm 4.0$ & $10.0 \pm 1.6$ & $<0.001$ \\
Neutrophils \% & $2.4 \pm 1.1$ & $1.8 \pm 0.4$ & $\mathrm{NS}$ \\
Eosinophils \% & $0.6 \pm 0.3$ & $0.3 \pm 0.1$ & $\mathrm{NS}$ \\
Mast cells \% & $0.3 \pm 0.1$ & $0.1 \pm 0.0$ & $\mathrm{NS}$ \\
CD3 $^{+}$T-cells \% & $91.4 \pm 1.3$ & $83.2 \pm 2.8$ & $<0.01$ \\
CD4 $^{+}$T-cells \% & $82.7 \pm 1.9$ & $52.2 \pm 6.6$ & $<0.001$ \\
CD8 $^{+}$T-cells \% & $13.1 \pm 2.2$ & $37.4 \pm 3.9$ & $<0.001$ \\
CD4/CD8 ratio & $8.4 \pm 1.3$ & $1.7 \pm 0.4$ & $<0.001$ \\
\hline
\end{tabular}




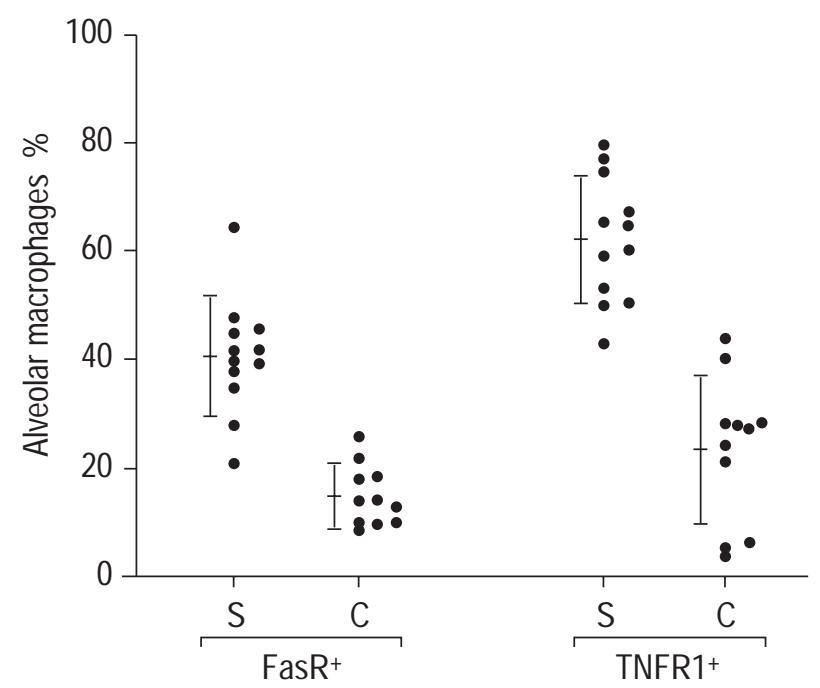

Fig. 1. - Expression of Fas receptor (FasR) and tumour necrosis factor receptor-1 (TNFR1) on alveolar macrophages in patients with sarcoidosis (S) and control subjects (C). Data presented as individual values and mean \pm SD.

\section{Discussion}

This study demonstrated that the expression of both FasR and TNFR1 on AM was increased in sarcoidosis. There was a close correlation between the percentage of FasR $^{+}$AM and TNFR $1^{+}$AM. Previous studies had reported that FasR was expressed by mouse macrophages and upregulated by interferon (IFN)- $\gamma$ [19], a potent activator of macrophages [20]. Another study demonstrated that TNFR1 was expressed by human monocytes [9] and synovial fluid macrophages [21] and upregulated by lipopolysaccharide (LPS) [22] and granulocyte-macrophage colony-stimulating factor (GM-CSF) [23]. The elevated expression observed in patients with sarcoidosis in the present study most likely reflects in vivo AM activation under the influence of the exaggerated cytokine production known to occur in this disease. This study also revealed that the expression of FasR and TNFR1 on AM correlated positively with the percentages of BAL lymphocytes and CD4 T-cell subsets and with the CD4/CD8 ratio, which are considered to be features of the local inflammatory activity.

When either FasR or TNFR1 on AM is triggered by its specific ligand, the AM undergoes apoptosis. Apoptosis of human AM can be induced by endotoxin and can be enhanced by the macrophage-activating cytokine IFN- $\gamma$ [24]. This cytokine is produced in exaggerated amounts by lymphocytes and macrophages in sarcoidosis [20]. In this regard it is interesting to note that patients with sarcoidosis who have higher serum levels of IFN- $\gamma$ have a better prognosis [25]. Apoptosis of human AM can be reduced by the macrophage-deactivating cytokines interleukin (IL)-4, IL-10, and transforming growth factor (TGF)- $\beta$ [25]. Apoptosis is controlled by the balance of inducers and inhibitors, the former including Fas ligand and TNF [1], the latter including soluble FasR (sFasR) [26] and Bcl-2 [27]. There is ample evidence of increased production of TNF- $\alpha$ by AM in sarcoidosis $[28,29]$. In addition to higher proportions of Fas ${ }^{+}$lymphocytes in aqueous humor than in peripheral blood lymphocytes, apoptosis of aqueous humor lymphocytes has been disclosed in uveitis from sarcoidosis [13]. However, the present study cannot answer if AM apoptosis occurs in sarcoidosis, since not all cell types expressing FasR undergo apoptosis following stimulation of the FasR [30].

Macrophages and AM-derived cytokines, especially TNF- $\alpha$, regulate pathological processes in sarcoidosis [16, $28,29,31,32]$. The present study showed that the expression of FasR or TNFR1 on AM was also related to the percentage of the CD14 ${ }^{+} \mathrm{AM}$ subset in BAL. CD14, a receptor for LPS [33], is expressed not only on monocytes but also highly expressed by mature AM in sarcoidosis $[29,34]$. Stimulation of this receptor induces a large release of TNF- $\alpha$ from AM [35]. In this regard, FasR and TNFR1 expression on AM may be considered as further signs of AM activation.

In conclusion, Fas receptor and tumor necrosis factor receptor-1 were expressed by human alveolar macrophages. The percentages of Fas-positive alveolar macrophages and of tumour necrosis factor receptor-1-positive alveolar macrophages were increased in patients with active sarcoidosis compared to control subjects, and correlated with the percentage of bronchoalveolar lavage lymphocytes and the CD4/CD8 ratio, as well as the percentage of the CD14positive alveolar macrophages. This may indicate that alveolar macrophages expressing apoptotic receptors are related to the local activity of the disease. Further studies are required to determine whether alveolar macrophages from patients with sarcoidosis undergo apoptosis more readily than those from control subjects.

\section{References}

1. Thompson CB. Apoptosis in the pathogenesis and treatment of disease. Science 1995; 267: 1456-1462.

2. Vaux DL, Haecker G, Strasser A. An evolutionary perspective on apoptosis. Cell 1994; 76: 777-779.

3. Golstein P, Ojcius DM, Young D-E. Cell death mechanism and the immune system. Immunol Rev 1991; 121:2965 .

4. Nagata S, Golstein P. The Fas death factor. Science 1995; 267: 1449-1456.

5. Smith CA, Farrah T, Goodwin RG. The TNF receptor superfamily of cellular and viral proteins: activation, costimulation, and death. Cell 1994; 76: 959-962.

6. Tartaglia LA, Ayres TM, Wong GHW, Goeddel DV. A novel domain with the $55 \mathrm{kD}$ TNF receptor signals cell death. Cell 1993; 74: 845-853.

7. Yonehara S, Nishimura Y, Kishil S, et al. Involvement of apoptosis antigen Fas in clonal deletion of human thymocytes. Int Immunol 1994; 6: 1849-1856.

8. Miyawaki T, Uehara T, Nibu R, et al. Differental expression of apoptosis-related Fas antigen on lymphocyte subpopulations in human peripheral blood. J Immunol 1992; 149: 3753-3758.

9. Imamura K, Spriggs D, Kufe D. Expression of tumor necrosis factor receptors on human monocytes and internalization of receptor bound ligand. J Immunol 1987; 139: 2989-2992.

10. Boussaud V, Soler P, Moreau J, Goodwin RG, Hance AJ. Expression of three members of the TNF-R family of receptors (4-1BB, lymphotoxin- $\beta$ receptor, and Fas) in human lung. Eur Respir J 1998; 12: 926-931.

11. Mysler E, Bini P, Drappa J, et al. The apoptosis-1/Fas protein in human systemic lupus erythematosus. $J$ Clin Invest 1994; 93: 1029-1034. 
12. Agostini C, Zambello R, Sancetta R, et al. Expression of tumor necrosis factor-receptor superfamily members by lung $\mathrm{T}$ lymphocytes in interstitial lung disease. $A m J$ Respir Crit Care Med 1996; 153: 1359-1367.

13. Ohta K, Norose K, Wang X, Ito S, Yano A, Segawa K. Apoptosis-related fas antigen on memory $\mathrm{T}$ cells in aqueous humor of uveitis patients. Curr Eye Res 1996; 15: 299-306.

14. Nomoto Y, Kuwato K, Hagimoto N, et al. Apoptosis and Fas/Fas ligand mRNA expression in acute immune complex alveolitis in mice. Eur Respir $J$ 1997; 10: 23512359.

15. Müller-Quernheim J. Sarcoidosis: immunopathogenetic concepts and their clinical application. Eur Respir J 1998; 12: 716-738.

16. Solbach W, Moll H, Röllinghoff M. Lymphocytes play the music but the macrophage calls the tune. Immunol Today 1991; 12: 4-6.

17. Thompson AB, Teschler H, Wang YM, Konietzko N, Costabel U. Preparation of bronchoalveolar lavage fluid with microscope slide smears. Eur Respir J 1996; 9: 603608.

18. Costabel U, Bross KJ, Matthys H. A new method for the demonstration of surface antigens on bronchoalveolar lavage cells. Bull Eur Physiopathol Respir 1985; 21: 381387.

19. Watanabe-Fukunaga $\mathrm{R}$, Brannan $\mathrm{CI}$, Itoh $\mathrm{N}$, et al. The cDNA structure, expression, and chromosomal assignment of the mouse Fas antigen. $J$ Immunol 1992; 148: 1274-1279.

20. Robinson BWS, McLemore TL, Crystal RG. Gammainterferon is spontaneously released by alveolar macrophages and lung T-lymphocytes in patients with pulmonary sarcoidosis. J Clin Invest 1985; 75: 1488-1495.

21. Hart PH, Hunt EK, Bonder CS, Watson CJ, FinlayJones JJ. Regulation of surface and soluble TNF receptor expression on human monocytes and synovial fluid macrophages by IL-4 and IL-10. J Immunol 1996; 157: 3672-3680.

22. Leeuwenberg JF, Dentener MA, Buurman WA. Lipopolysaccharide LPS-mediated soluble TNF receptor release and TNF receptor expression by monocytes. Role of CD14, LPS binding protein, and bactericidal/permeability-increasing protein. $J$ Immunol 1994; 152: 5070 5076.

23. Williams MA, Kouroumoussis J, Syndercombe-Court D, Hendry L, Newland AC, Kelsey SM. Administration of recombinant human granulocyte-macrophage colony-stimulating factor after chemotherapy regulates the expres- sion and secretion of monocyte tumor necrosis factor (TNF) and TNF receptors p55 and p75. Blood 1995; 86: 4234-4242.

24. Bingisser R, Stey C, Weller M, Groscurth P, Russi E, Frei $\mathrm{K}$. Apoptosis in human alveolar macrophages is induced by endotoxin and is modulated by cytokines. Am J Respir Cell Mol Biol 1996; 15: 64-70.

25. Prior C, Haslam PL. Increased levels of serum interferongamma in pulmonary sarcoidosis and relationship with response to corticosteroid therapy. Am Rev Respir Dis 1991; 143: 53-60.

26. Cheng J, Zhou T, Liu C, et al. Protection from Fasmediated apoptosis by a soluble form of the fas molecule. Science 1994; 263: 1759-1762.

27. Itoh N, Tsujimoto Y, Nagata S. Effect of bcl-2 on Fas antigen-mediated cell death. $J$ Immunol 1993; 151: 621627.

28. Pueringer RJ, Schwartz DA, Dayton CS, Gilbert SR, Hunninghake GW. The relationship between alveolar macrophage TNF, IL-1, and PGE2 release, alveolitis, and disease severity in sarcoidosis. Chest 1993; 103: 832838.

29. Zheng L, Teschler H, Guzman J, Hübner K, Striz I, Costabel U. Alveolar macrophage TNF- $\alpha$ release and BAL cell phenotypes in sarcoidosis. Am $J$ Respir Crit Care Med 1995; 152: 1061-1066.

30. Lynch DH, Ramsdell F, Alderson MR. Fas and FasL in the homeostatic regulation of immune responses. Immunol Today 1995; 16: 569-574.

31. Spiteri MA, Clarke SW, Poulter LW. Alveolar macrophages that suppress T-cell responses may be crucial to the pathogenetic outcome of pulmonary sarcoidosis. Eur Respir J 1992; 5: 394-403.

32. Minshall EM, Tsicopoulos A, Yasruel Z, et al. Cytokine mRNA gene expression in active and nonactive pulmonary sarcoidosis. Eur Respir J 1997; 10: 2034-2039.

33. Ziegler-Heitbrock HWL, Ulevitch RJ. CD14: cell surface receptor and differentiation marker. Immunol Today 1993; 14: $121-125$.

34. Striz I, Zheng L, Wang YM, Pokorna H, Bauer PC, Costabel U. Soluble CD14 is increased in bronchoalveolar lavage of active sarcoidosis and correlates with alveolar macrophage membrane-bound CD14. Am J Respir Crit Care Med 1995; 151: 544-547.

35. Dentener MA, Bazil V, Von Asmuth EJU, Ceska M, Buurman WA. Involvement of CD14 in lipopolysaccharide-induced tumor necrosis factor-a, IL-6 and IL-8 release by human monocytes and alveolar macrophages. $J$ Immunol 1993; 150: 2885-2891. 